\title{
Academic Engagement in Public and Political Discourse: Establishing the Rules of the Game
}

\author{
ANDREW J. HOFFMAN \\ Volume 1, Fall 2013 \\ DOI: http://dx.doi.org/10.3998/mjs.12333712.0001.003
}

A recent study in Environmental Research Letters found that, of the more than 4,000 academic papers published between 1991 and 2011, 97.1\% agreed that climate change is occurring and is anthropogenic (Cook et al. 2013). This supports numerous other studies showing similarly conclusive results (e.g., Oreskes 2004). And yet the most recent surveys of public attitudes on climate change show that only $65 \%$ of American adults believe that there is solid evidence that temperatures on earth have increased during the past four decades (Borick and Rabe 2012), and the number of Americans who believe that "most scientists think global warming is happening" declined from 47\% to 39\% between 2008 and 2011 (Ding et al. 2011).

There are numerous explanations for this startling disconnect between the scientific consensus around climate change (American Association for the Advancement of Science 2006) and the lack of a social consensus:

- Motivated reasoning. People's pre-existing beliefs about climate change will lead them to find supportive evidence of those beliefs (Kahan 2010).

- Political partisanship. The percentage of conservatives and Republicans who believe that the effects of global warming have already begun to happen declined from roughly $50 \%$ in 2001 to about $30 \%$ in 2010, while the corresponding percentage of liberals and Democrats increased from roughly $60 \%$ in 2001 to about 70\% in 2010 (McCright and Dunlap 2011).

- Conflicting cultural values. Debates over climate change invoke deeper cultural issues around distrust of science, fear of increasing government, suspicion of the motives of environmentalists, and challenges to notions of God and divine providence (Hoffman 2012a).

- Political power. There are organizations whose economic and political interests are threatened by efforts to address climate change and have engaged in active efforts to confuse the public debate (Oreskes and Conway 2010). 
One explanation that requires more direct attention is the failure of the academic and scientific communities to effectively explain the state and gravity of the science behind climate change. Academic scholars are simply not trained, nor are they given the proper incentives, to do this kind of work. But this needs to change.

The Michigan Journal of Sustainability, "whose purpose is to translate and integrate sustainability research from a wide range of fields" to "support a greater global exchange of knowledge" among scientists, practitioners, and policymakers, is a timely and critical step in the right direction. It is an opportunity to create an outlet for emerging and seasoned scholars to communicate their science to the public and policy makers. There is simply too much at stake for knowledgeable scientists to sit on the sidelines, focusing solely on engagement within their scholarly communities. They must become more engaged.

In our increasingly technological world, issues like nanotechnology, stem-cell research, nuclear power, climate change, vaccines and autism, genetically modified organisms, and endocrine disruption require thoughtful and informed debate. For this to happen, we need a more socially literate scientific community and a more scientifically literate public. In regards to the latter, the data is not encouraging. A survey by the California Academy of Sciences shows that the majority of the U.S. public is unable to pass even a basic scientific literacy test (California Academy of Sciences 2009), and the National Science Foundation reports that two-thirds of Americans do not clearly understand the scientific process (National Science Foundation 2004).

To fix this deficiency, we need improvement in the former: scientists who can be effective communicators of the scientific issues of our day. What we need is new Carl Sagans, people who can take complex scientific ideas and make them understandable to a lay audience. We need people who can present this information in ways that recognize its deep cultural underpinnings, reaching all demographics, young and old, poor and affluent, liberal and conservative.

Unfortunately, many excellent scientists are poor communicators who lack the skills or inclination to play the role of educator to the general public. Further, many scientists view this role as outside their domain of responsibilities (Besley and Nisbet, 2011). As the prevailing logic goes, scientists develop data, models, and conclusions and expect society to accept their conclusions because their methods and their interests are established within their scientific communities and should not be questioned. But science is never socially or politically inert, particularly when it results in changes in the way people live their lives, and scientists have a duty to both recognize its impact on society and communicate that impact to those who 
must live with the consequences (Hoffman 2012b). The poor state of the public debate on climate change is, in part, the responsibility of the academic community. The challenge facing both the scientific community and society on climate change is about science communication (Fischoff 1995; Slovic 1987), not the science itself.

In this inaugural issue of the Michigan Journal of Sustainability, I want to start a conversation on how academic scientists can and should engage in public debates. I think that we need to carefully assess the rules of engagement and be cognizant that there are hazards along the way. Scholars may find themselves crossing the line into biased advocacy without knowing it, losing the legitimacy of the objective academic scholar within the academy. Having lost this legitimacy, they may find both their voice in public debates and chances at promotion diminished. With this goal as a starting point, I want to offer twelve Rules of Engagement as points of discussion that I hope future writers in this journal will debate. I do not offer them as the definitive final word.

1. Define the proper role. What is the proper role that the academic scientist should play in public and policy debates? Roger Pielke, Jr. (2007) describes four archetypal roles. The first is the Honest Broker, one who provides as much information as possible on a particular topic and allows policy makers and the public to reduce the scope (i.e., make a decision). The Honest Broker "expand[s] the scope of choice available to decision-makers . . . and explicitly integrate[s] scientific knowledge with stakeholder concerns in the form of alternative possible courses of action." Pielke differentiates this role from those of the Pure Scientist who focuses on research with no consideration for its use or utility (a role which he states is more frequently found in myth than practice), the Issue Advocate who focuses on the "implications of research for a particular political agenda" and "tends to reduce the scope of available choice," and the Science Arbiter who will answer questions from decision makers to clarify research (i.e., the National Academies). This structure, and the goal of the Honest Broker, is accepted by some, contested by others and worthy of spirited discussion. But having a clear delineation of the archetypes of engagement is an important first step in moving outside the realm of the academy.

2. Recognize the rules of academia. An academic scientist can best enter the public debate from the security of tenure. Junior faculty members must remain aware that the academic model is an apprenticeship model, 
and young scientists must earn their place within the academic community through tenure before engaging in public discourse. The route to tenure is still based on academic scholarship, not public engagement. While one may choose to make brief forays into the public debate before tenure, public engagement should increase as one's career advances.

3. Stay within your area of expertise. Academic public engagement should remain within the boundaries of our expert knowledge. To remain a knowledgeable source, we should not drift too far outside our area of specialization. Economists should be careful when commenting on climate modeling, and climate scientists should be careful when commenting on cap-and-trade policies - if in fact they should comment at all. Leaving one's area of expertise is tricky territory for the Honest Broker. The safer and stronger way to do this is through inter-disciplinary engagement. Economists and climate scientists would ideally collaborate to develop coordinated and deeply grounded conclusions and recommendations.

4. Recognize our multiple selves. We are, of course, both academics and public citizens, and we should exercise our rights as citizens in domains that may (or may not) lie outside our domains of expertise. We can talk abstractly about "putting on different hats," but in practice that is not so easy or clear. When we lend our name to notably political issues (such as the recent referendum on a Renewable Portfolio Standard here in Michigan: " $25 \%$ by 2025 "), we must be careful to declare when we are speaking from our research and science, and when we are speaking from our concerns as citizens of this country (e.g., through the title or email we use when signing petitions or speaking in public forums).

5. Recognize the messiness of public debate. Public debate plays by a different set of rules than academic debate, and those who choose to engage should be prepared for unfamiliar tactics and players. A useful model is that of the "social amplification of risk": "Messages about risk emerge from one part of the system (e.g., scientists), the threat is then amplified by other actors in the system (e.g., activists and politicians) and downplayed by others (e.g., corporate interests) leading over time to changes in mass media coverage, public opinion, consumer markets and government policy" (Leiserowitz et al. 2012: 3). Then, ultimately, the multiple messages are consumed by the general public, who form opinions that either support or resist policies designed to deal with it (Kasperson et al. 1988). The secondary and tertiary ripple effects of this process can be 
quite large (Leiserowitz et al. 2012). For example, scientists wrote papers in 2013 to explain the relatively flat temperature measurements for the previous five years and what those data meant for climate models; those papers are then summarized in articles in other domains (like the business journal The Economist); that article is then repeated (and often distorted) through multiple editorials, blogs, and tweets to promote a particular viewpoint; conservative pundits sum up the entire conversation to argue that it proves that climate change is a hoax (as Rush Limbaugh did); and the public becomes further confused. Through it all, scientists lose control of the message they intended their data and models to convey. The upshot of this process is that scientists should be committed to a protracted and messy engagement in order to make their voices heard.

6. Recognize the politics and hostility of public debate. The public debate on issues like climate change is not for the faint of heart. I have received my share of hate mail for my work on the social debate over climate change: "you are doing the work of Satan," "Are you an idiot deceiver or just plane [sic] stupid? I have news for you. $\mathrm{CO}_{2}$ is plant food," "Your days of milking the system with your phony science are numbered," "Warming terrorists need a spanking." This kind of vitriolic engagement is certainly outside the realm of our training or our usual form of intellectual exchange. And it stings when first received. But in the words of an old aphorism, "If you are not offending anyone, you never took a stand." If you truly have something important to offer to the public debate, you will get blowback. That doesn't necessarily mean that you are wrong or that you presented your ideas inappropriately. You just need to be ready to receive it.

7. Reconsider your publication strategy. Typically, we do our research, write it up, submit it for review, revise and resubmit it, publish it and we are done. But public engagement challenges us to take the work further, finding ways to present it in forums and media that are more accessible to a general audience. We can write editorials, speak on radio shows, write for practitioner journals, speak at practitioner audiences, give government testimony, write blogs, tweet, and on and on. We live in a world where the marketplace of ideas is becoming an increasingly public one. Don't just stop with the academic paper.

8. Recognize that not all outlets may be legitimate for an academic scientist. An expansion of one's publication strategy raises the question of 
which outlets are appropriate and productive. There is a wide range of outlets available to the academic scientist, many of which span the spectrum of news to entertainment, conservative to liberal, thoughtful to sensational. The menu of blogs, e-zenes, talk shows and other outlets is steadily expanding, and the academic scholar must give careful consideration to which are genuine and constructive forms of public engagement. As an example, consider the range of talk shows available to scholars today (The Daily Show, The Colbert Report, The Bill Maher Show, The Glenn Beck Show, The Rush Limbaugh Show, Entertainment Tonight, The Howard Stern Show, The Jerry Springer Show, Jay Leno, Bill Moyers-and the list goes on). Certainly there are talk shows on this list that cross the line of being constructive for credibly communicating with the public and credibly advancing in one's academic field. Where do we draw the line?

9. Recognize multiple roles in the science communication process. Scientific advancement is a collective activity, with multiple roles for multiple individuals. The notion of a single Carl Sagan in today's complex and politically charged environment is highly implausible. Instead, we should seek to play a role that best suits our skills, temperament and inclinations. Pidgeon and Fischoff (2011: 39), for example, offer a model for the coordination of multiple roles within climate science: "(1) Subjectmatter experts to present the latest scientific findings, (2) Decision scientists who can identify the most relevant aspects of that science and summarize it concisely, (3) Social and communication scientists who can assess the public's beliefs and values, propose evidence based designs for communicating content and processes, and evaluate their performance, and (4) Program designers who can orchestrate the process, so that mutually respectful consultations occur, messages are properly delivered, and policymakers hear their various publics." Somewhere along this process is a place for multiple scholars, as well as a line between the domain of the academic and the domain of the advocate.

10. When necessary, employ science translators. Not everyone can effectively engage the public and political debate, nor should they. Speaking to lay audiences is, in many ways, like speaking another language. Sometimes we need translators: editors, coaches and communications professionals to help us reach external audiences.

11. Seek out good role models. Good role models are necessary for emulating a successful career path that includes public engagement. This ter- 
rain is not well mapped out, and scholars need examples from which to draw for their own career path. We need ways to call attention to these examples and highlight their path-breaking lessons.

12. Change the rules of academia. My list ends where it began: we must recognize the limits of the existing academic structure and seek to change it where possible. These limits begin with our training in doctoral programs and continue through our professional development as scholars. In both cases, the constant immersion in academic seminars and journals to the exclusion of practitioner seminars, meetings and journals weakens our literacy in the languages of the larger mass of people. We need to change doctoral training and tenure criteria so that writing for practitioner journals, speaking at practitioner conferences, writing trade books or some other metric of external impact registers as valuable. We need to foster collaboration over competition (Walsh, Weber, and Margolis 2003) and recognize that our worth is based not only on our singular efforts at publishing in top-tier journals but also on our ability to build bridges between practitioners and academics as well as among academics of different kinds.

So, in this first issue of the Michigan Journal of Sustainability, I offer a challenge, one that I hope future contributors will take on. While this journal and the discussions within it are important contributions to exploring and defining the rules of public engagement for the academic scholar, this first issue is just a start. The format needs to continue to change and the scholars who write papers within it need to do more than just write something and put it online. I would like to see this journal become a catalyst and explore the boundaries of additional pathways for academic scholarship to benefit both individual scholars and the society that can learn from their work.

For the individual scholar, the simple fact is that a satisfying career will be based more on the ways we have impacted how people think and act than on citation counts and top-tier journal articles. For society, the solutions to the great sustainability problems of our day require the contribution of sound science and analysis. We cannot develop a scientifically literate electorate, or indeed a sound democracy, without the voice of scientists to explain the methodology, results and implications of their work. I think of academia as a special and honored place in society (March 2003), not above it or separate from it, but part of it. And as members of society, we have a responsibility to bring our expertise to the decision-making process (Meyer 
et al. 2010). Those of us who are privileged enough to live the life of an academic bear a responsibility to contribute to the world around us. Or as John F. Kennedy said, "To those whom much is given, much is expected."

\section{References}

American Association for the Advancement of Science. 2006. AAAS Board Statement on Climate Change. Accessed May 16, 2013. http://www.aaas.org/news/press_room/climate_change/ mtg_200702/aaas_climate_statement.pdf.

Besley, J. and M. Nisbet. 2013. "How Scientists View the Public, the Media and the Political Process," Public Understanding of Science, 22(6): 644-659.

Borick, C., and B. Rabe. 2012. Continued Rebound in American Belief in Climate Change: Spring 2012 NSAPOCC Findings. Washington DC: Brookings Institution.

California Academy of Sciences. 2009. "American Adults Flunk Basic Science." Accessed August 24, 2011. http://www.calacademy.org/newsroom/releases/2009/scientific_literacy.php.

Cook, J., D. Nuccitelli, S. Green, M. Richardson, B. Winkler, R. Painting, R. Way, P. Jacobs, and A. Skuce. 2013. "Quantifying the Consensus on Anthropogenic Global Warming in the Scientific Literature.” Environmental Research Letters 8 (2013). doi: 10.1088/1748-9326/8/2/024024. http://dx.doi.org/10.1088/1748-9326/8/2/024024

Ding, D., E. Maibach, X. Zhao, C. Roser-Renouf, and A. Leiserowitz. 2011. "Support for Climate Policy and Societal Action Are Linked to Perceptions about Scientific Agreement." Nature Climate Change 1:462-466. http://dx.doi.org/10.1038/nclimate1295

Fischhoff, B. 1995. "Risk Perception and Communication Unplugged: Twenty Years of Process." Risk Analysis 15 (2): 137-145. http://dx.doi.org/10.1111/j.1539-6924.1995.tb00308.x

Hoffman, A. 2004. "Reconsidering the Role of the Practical-Theorist: On (Re)connecting Theory to Practice in Organizational Theory." Strategic Organization 2 (2): 213-222. http://dx.doi. org/10.1177/1476127004042845

Hoffman, A. 2012a. "Climate Science as Culture War." Stanford Social Innovation Review 10 (4): $30-37$.

Hoffman, A. 2012b. "Warm Spring Weather and Global Warming: If Scientists Could Only Be So Persuasive." Christian Science Monitor, March 21.

Kahan, D. 2010. "Fixing the Communications Failure." Nature 463 (21): 296-297. http://dx.doi. org/10.1038/463296a

Kasperson, R., O. Renn, P. Slovic, H. Brown, J. Emel, and R. Goble. 1988. "The Social Amplification of Risk: A Conceptual Framework." Risk Analysis 8:177-187. http://dx.doi. org/10.1111/j.1539-6924.1988.tb01168.x

Leiserowitz, A., E. Maibach, C. Roser-Renouf, N. Smith, and E. Dawson. 2012. "Climategate, Public Opinion, and the Loss of Trust." American Behavioral Scientist 57 (6): 818-837. http:// dx.doi.org/10.1177/0002764212458272

March, J. 2003. "A Scholar's Quest.” Journal of Management Inquiry 12 (3): 205-207. http:// dx.doi.org/10.1177/1056492603256272

McCright, A., and R. Dunlap. 2011. "The Politicization of Climate Change and Polarization in the American Public's Views of Global Warming, 2001-2010,” The Sociological Quarterly 52:155- 
194. http://dx.doi.org/10.1111/j.1533-8525.2011.01198.x

Meyer, J., P. Frumhoff, S. Hamburg, and C. de la Rosa. 2010. "Above the Din but in the Fray: Environmental Scientists as Effective Advocates." Frontiers in Ecology and Environment 8:299305. http://dx.doi.org/10.1890/090143

National Science Foundation. 2004. "Science and Technology: Public Attitudes and Understanding." Science and Engineering Indicators 2004. Accessed August 24, 2011. http://www.nsf.gov/ statistics/seind04/c7/c7h.htm.

Oreskes, N. 2004. "The Scientific Consensus on Climate Change." Science 306 (5702): 1686. http://dx.doi.org/10.1126/science.1103618

Oreskes, N., and E. Conway. 2010. Merchants of Doubt: How a Handful of Scientists Obscured the Truth on Issues From Tobacco Smoke to Global Warming. New York: Bloomsbury Press.

Pidgeon, N., and B. Fischoff. 2011. "The Role of Social and Decision Sciences in Communicating Uncertain Climate Risks." Nature Climate Change March: 35-41.

Pielke, R. 2007. The Honest Broker: Making Sense of Science in Policy and Politics. Cambridge, UK: Cambridge University Press. http://dx.doi.org/10.1017/CBO9780511818110

Slovic, P. 1987. "Perception of Risk.” Science 236 (4799): 280-285. http://dx.doi.org/10.1126/ science. 3563507

Walsh, J., K. Weber, and J. Margolis. 2003. "Social Issues and Management: Our Lost Cause Found." Journal of Management 29 (6): 859-81. 